\title{
AZ ÓKERESZTÉNY TEMETŐ ÉS IDRISZ BABA TÜRBÉJE
}

\section{THE EARLY CHRISTIAN BURIAL SITES AND THE TÜRBE OF IDRIS BABA}

\author{
Major Róbert ${ }^{1}$, Kósa Balázs ${ }^{2}$, Molnár Tamás ${ }^{3}$ \\ ${ }^{1}$ Pécsi Tudományegyetem Müszaki és Informatikai Kar, Vízuális Ismeretek Tanszék, \\ H-8654, Magyarország, Ságvár, Viola utca, 8; Telefon: 06208521 664, ma- \\ jor.robi1192@gmail.com \\ ${ }^{2}$ Pécsi Tudományegyetem Müszaki és Informatikai Kar, Vízuális Ismeretek Tanszék, \\ H-7625, Pécs, Ilona utca 23; Telefon: 06305399 616, kosa.balazs.84@gmail.com \\ ${ }^{3}$ Pécsi Tudományegyetem Müszaki és Informatikai Kar, Vízuális Ismeretek Tanszék, \\ H-7624, Pécs Boszorkány út 2 / B341 iroda; Telefon: 06703383 183, \\ tmolnar@pmmik.pte.hu
}

\begin{abstract}
The city of Pécs was already an important commercial and religious center in ancient times. Because of the city's location, it has become one of the most important cultural hubs in Central Europe. In Pécs, in various historical times, many different cultures have flourished and one of the most typical imprints of these cultures are cemeteries and burial buildings. The subject of our research is to compare Idris baba's türbe with another iconic heritage of Pécs, the Early Christian Cemetary, furthermore as an example of this cemetery's visitor center, designing a plan that reattaches the neglected turkish cemetery into the city's life.
\end{abstract}

Keywords: monument, turkish, Pécs, downtown, türbe.

\section{Összefoglalás}

Pécs városa már az ókorban is fontos kereskedelmi és vallási központ volt. A város elhelyezkedéséből adódóan Közép-Európa egyik legfontosabb kulturális csomópontjává nőtte ki magát. Pécsen a különböző történelmi korokban sok különféle kultúra megfordult és ennek egyik legjellemzőbb lenyomata a temetők, temetkezési épületek. Kutatásunk témája egy ilyen épület Idrisz Baba türbéjének összehasonlítása egy másik ikonikus pécsi síregyüttessel, az ókeresztény temetővel, valamint eme temető látogatóközpontjának példájára egy terv készítése, ami visszakapcsolja a város életébe az elhanyagolt török kori sírépítményt.

Kulcsszavak: müemléki épület, török, Pécs, belváros, türbe.

\section{Bevezetés}

A mai szükülő világban egyre jobban jellemző a nagyobb városokra, hogy a különböző kultúrák keverednek egymással. Ez a jelenség hazánkban fokozottan érezhetö.
Magyarország Kelet és Nyugat határán fekszik és mindkettőhöz tartozik is. A történelem során hol keleti, hol nyugati befolyás alá került a Kárpát-medence. Magyarországon egy olyan egyedülálló épített környezet található, ahol fellelhetők a nyugati stílusú 
épületek, de találhatók keleties behatások is. Az országba is fokozottan érdekes ilyen szempontból Pécs városa. A legszimbolikusabb példa erre Gázi Kaszim pasa dzsámija, mivel a tetején egy olyan kereszt áll, minek talpa egy félhold, ezzel jelképezve az épület kettősségét, mint keresztény templom és török dzsámi.

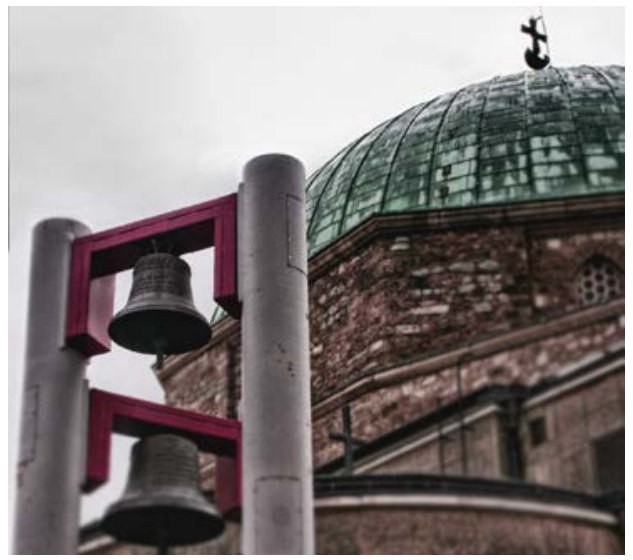

1. ábra. Gázi Kaszim pasa dzsámija

A város műemlékei jellegzetes hangulatot kölcsönöznek az egész településnek ezért kiemelten fontos, hogy megfelelö odafigyeléssel és szakértelemmel bánjunk ezekkel az épületekkel. Vannak olyan müemlékek a városban, amik rejtve vannak, az átlagember szeme elöl. Ilyen például a török hódoltságból Idrisz Baba türbéje, ami egyike a megmaradt két magyarországi türbének.

Ezért is választottuk kutatásunk témájaként. Célunk a Cella Septichora látogatóközpont mintájára egy olyan épület bemutatása és bekapcsolása a városi életbe, ami szintén építészettörténeti jelentőséggel bír. Ezért összehasonlítjuk az ókeresztény és a török épületeket, majd egy építészeti terven keresztül teszünk javaslatot a türbe és annak környezetének jövőjére.

\section{Történelmi áttekintés és össze- hasonlítás}

\subsection{Pécsi temetkezés}

Pécs környéke már az őskortól kezdve lakott terület így nem meglepő, hogy a város területén számos temető volt és van. Egy-egy városrészben az idők múltával temetkeztek a rómaiak, a hunok, magyarok és a törökök is a különböző kultúrák és vallások temetkezési szokásai egyedülálló lenyomatot hagytak a városban.

A temetők általában a város szélein helyezkedtek el, ahogy nött a város úgy tolódtak egyre kijjebb és kijjebb.

\section{2. Ókeresztény temető [1]}

Az ókorban Pécset Sopianæ-nek nevezték és története a II. századig nyúlik vissza. 293 után pedig a Dél-Dunántúl legjelentősebb városaként, Pannónia provincia Valeira tartományának közigazgatási központja lett. Az ide érkező rómaiak az élet minden területéről magukkal hozták a római kultúrát. Ugyanakkor kezdett teret hódítani délről a korai kereszténység, így a két kultúrának egy furcsa ötvözete alakult ki, a lassan kereszténnyé váló lakossággal.

Az ókeresztény temető képe valószínüleg hagyományosan a birodalom szerte elterjedt szokásokat tükrözte: hamvasztás, sírkőállítás, pogány sírmellékletek. De az idő múltával Sopianae megtelt gyönyörủen kifestett, az épületek alatt húzódó sírkamrákkal. A feltárt emlékek mind építészetileg, mind művészetileg páratlan alkotások, amelyek 2000 óta az UNESCO világörökség részét képezik.

\subsection{Idrisz Baba türbéje [2]}

Idrisz Babáról sok féle történet kering egyesek úgy tartják hogy orvos volt mások harcos szerzetesként (bektasi dervish) írnak róla. A pécsi Rókús dombon eltemetett szent köré több legenda is füződik. Először a két nagy török történetíró említi meg Ibrahim Pecsevi és Elia Cselebi. Mindketten 
írnak a szentről és a sírjáról is, kettőjük közül Ibrahim beszámolója tünik hitelesebbnek. Idrisz Baba türbéje az évszázadok során sokféle funkciót ellátott. Volt kápolna, korház, lőpor és kötszer raktár is. Míg végül a múlt században újra felfedezték és műemléki védettség alá helyezték. ekkor kezdődtek meg a felújítások és a kutatások. Az 1960-as években a környéken és az épületben is régészeti ásatásokat végeztek valamint teljes átfogó szerkezeti vizsgálatra is sor került. Érdekes módon a régészek nem találtak más építményekre utaló jeleket a környéken ez azért furcsa, mert az ilyen jelegü épületek kolostorok vagy egyéb épület komplexumok részeként épültek.

Az épület egy nyolcszög alaprajzú kupolával fedett terméskő építmény. A falai vakolatlanok mivel nem találtak megfelelö mintákat a restauráláshoz, így jól megfigyelhetők a különböző korok átalakításai.

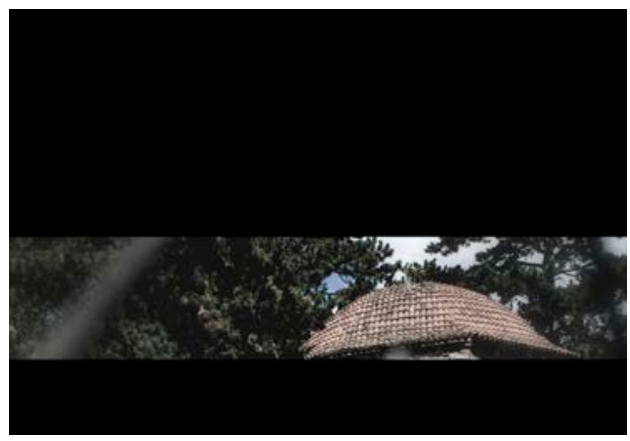

2. ábra. Idrisz Baba türbéje

\section{6. Összehasonlítás}

Furcsa lehet, párhuzamba állítani ezt a két fajta sírépítményt, hiszen különböző korból és különböző kultúrából is származnak. Az viszont kifejezetten érdekes hogy e két kultúra a helyi anyagokból egymástól függetlenül mennyire hasonló épületeket hozott létre. Az ókeresztény sírkamrák formai világa az antik kultúrát tükrözik, míg a türbe a közel kelet és a nomád népek hagyományain alapszik. Az pedig külön figyelemre méltó hogy Pécsen bár évszázad- ok múltak el itt mégis egy szük területre koncentrálódnak ezek a maradványok.

\section{A terv bemutatása}

Idrisz Baba türbéjét jelenleg egy kerítés különíti el a kórháztól és a Nyár utcától. Ennek az egyik oka, hogy a Nyár utca felé egy támfalat kellett elhelyezni a Mecsekből lefolyó víz miatt. Az általunk készített terv lényege, hogy ezt a kieső építészettörténeti emléket visszaillesszük a város mindennapjaiba. Ahhoz, hogy ez lehetséges legyen egy olyan közparkot terveztünk, ahol a zöld felületek és a burkolt terek pihenésre alkalmas parkká állnak össze, valamint létrejön egy kisebb tér a türbe körül, így a látogathatóság és az ismeretterjesztés is könnyebbé válik. A park fő irányvonalait a türbe oldalaihoz illesztve alakítottuk ki, így a Nyár köz és a Nyár utca sarkához képeset egy eltolt centrális teret kapunk, aminek a központja maga a türbe. Az utcától való elszigetelődést a támfal megnyitásával és átalakításával kívánjuk orvosolni. Az általunk kialakítani kívánt támfal egy modern betonfal, amiben a megnyitások úgy helyezkednek el, hogy azok ne okozzanak gondot a vízelvezetésben, mégis láthatóan és egyszerüen megközelíthetővé tegyék a müemléket. A támfal magasságában leköveti a terepszintet és ehhez viszonyul mindenhol.

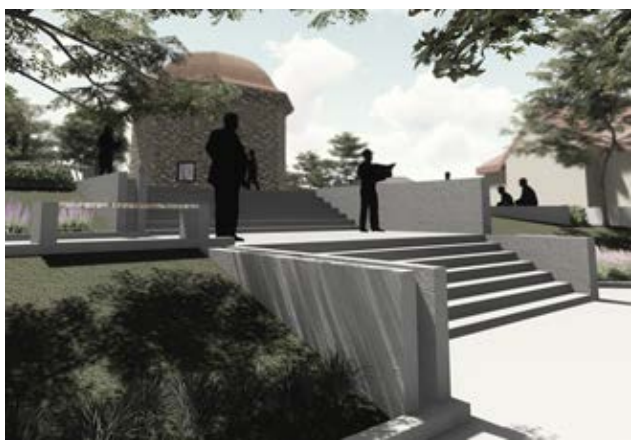

3. ábra. Látványterv áttervezet parkról 
A park kialakítását az Iszlám temetkezési szokások és az muzulmán temetők ihleték. A park fő irányvonalain kívül eső utakat egy hagyományos Iszlám motívumból (Rub el Hizb: A Korán fejezeteinek végét jelöli.) szerkesztett raszter mentén kaptuk meg. Ezen utak mentén a víz, mint az egyik legerősebb vallási szimbólum időről-időre megjelenik, valamint a fó útvonal kezdetén és a türbe mellet medencékben tünik fel. Az utak mentén a zöld felületekben füszernövényeket, (például: rozmaring és babér), valamint törpe örökzöldeket és egyéb erős illatú növényeket (levendula, jázmin) tereztünk. Ennek az az oka, hogy az muzulmán ravatalozásnál a mai napig növényekkel, illóolajokkal dörzsölik be a testet. Sajnálatos módon a jelenleg meglévő nagyobb fák olyan fenyők, amik nem viselnék el az építkezéssel járó földmunkát így inkább egy új fásítás mellet döntöttünk. A fák fajtáinak kiválasztásakor is szem előtt tartottuk a túlvilági létet és az elmúlást, amit, mint a sírhely, a türbe jelképez, ezért olyan növényeket ajánlanánk, mint a ciprus félék, valamint a fenyők esetleg kisebb lombos fák, fügefa, selyemakác. Esetleg szimbolikus értéke miatt, a ginkgo biloba. A tér és az utak burkolata fehér térkő, ez a színvilág továbbra is az muszlim temetőkből ered. Az árnyékolás kérdését a fásítás mellet ideiglenesen kihelyezhető fehér vászonárnyékolók biztosíthatják, amik ismét a török temetkezésből vett szimbólumok.

A kérdéses terület egy olyan helyen fekszik, ami a pécsi egyetemisták által használt egyik legforgalmasabb útvonal. Ez abban is meg mutatkozik, hogy a környéken több étterem és pub is található. De nem csak az egyetemisták miatt forgalmas része ez a városnak itt található a gyermekkórház, a szülészet, és egyéb egészségügyi épületek is. A türbe környezetének átalakításával egy olyan park jöhetne léte, ahol a diákok pihenhetnek, valamint az ide érkezők is egy kellemesebb közeget találnak.

\section{Szakirodalmi hivatkozások}

[1] Hudák Krisztina - Nagy Levente: Örökség füzetek 6. Nemzeti Kulturális Alap, Pécs, 2009, 9-62

[2] Sudár Balázs: A pécsi Idrisz Baba-türbe. Forster Gyula Nemzeti örökséggazdálkodási és szolgáltatási Központ, Budapest, 2013, 43-67.

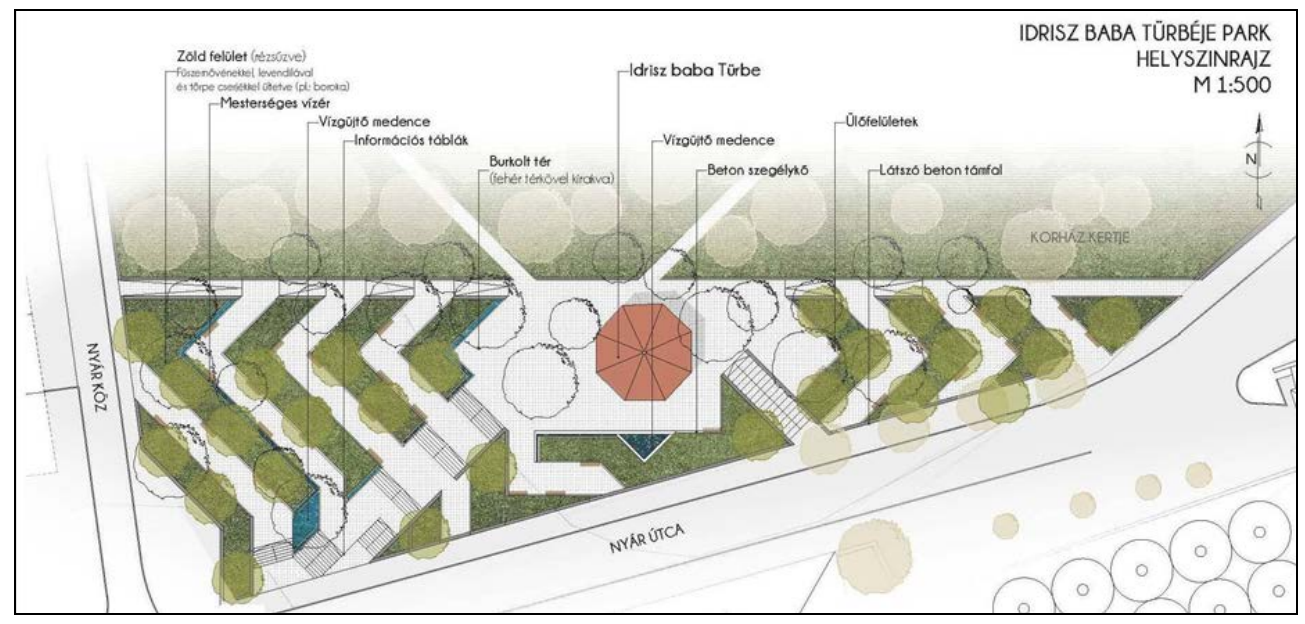

4. ábra. A tervezet park helyszínrajza 